\title{
Contributions of the Base Erosion and Profit Shifting BEPS Project on Transfer Pricing and Tax Avoidance
}

\author{
http://doi.org/10.21272/fmir.5(3).59-70.2021
}

Anissa Ouelhadj, ORCID: https://orcid.org/0000-0002-3159-3203

Master Student, MDI Algiers Business School, Algeria

Mehdi Bouchetara, ORCID: https://orcid.org/0000-0001-9826-8985

Dr., Higher National School of Management, Algeria

\begin{abstract}
Globalization and digitalization lead to flaws and asymmetries in tax rules which were used by multinational companies in their own benefit. Then, to face tax avoidance and tax losses which represents 100 to 240 billion dollars per year, Organization for Economic Co-operation and Development and G-20 implement, since 2012, the Base Erosion and Profit Shifting project, base erosion and profit shifting, which is the most important international reform that tax system has known. This paper aims to understand whether the Base Erosion and Profit Shifting project's transfer pricing actions mitigate tax avoidance by multinationals through a literature review and a qualitative approach. We interview 05 international tax specialists working in Multinational Companies and Tax Administration. We found that the project's transfer pricing reforms mitigate tax avoidance in short term. We confirm the first hypothesis, that the Base Erosion and Profit Shifting project's transfer pricing inputs mitigate tax avoidance in the short term, and following the results obtained, we refute the second hypothesis that Base Erosion and Profit Shifting actions dealing with transfer pricing do not mitigate tax avoidance.
\end{abstract}

Keywords: BEPS, Transfert Pricing, Tax Avoidance, Multinational Company, Tax Administration, OECD.

JEL Classification: H23, H26, H32.

Cite as: Ouelhadj, A., Bouchetara, M. (2021). Contributions of the Base Erosion and Profit Shifting BEPS Project on Transfer Pricing and Tax Avoidance. Financial Markets, Institutions and Risks, 5(3), 5970. http://doi.org/10.21272/fmir.5(3).59-70.2021

Received: 12, August, 2021

Accepted: 6, September, 2021

Published: 13, September, 2021

Copyright: (C) 2021 by the authors. Licensee Sumy State University, Ukraine. This article is an open access article distributed under the terms and conditions of the Creative Commons Attribution (CC BY) license (https://creativecommons.org/licenses/by/4.0/)

\section{Introduction}

The international tax system, conceived more than a century ago, has put in place a number of rules that govern a country's cross-border transactions with another country, using bilateral conventions (Chaouche, 2019), the aim is to eliminate double taxation of multinational enterprises in the source country and the residet country (OCDE, 2015). However, as international tax rules are complex and contain loopholes due to existing discrepancies and asymmetries, they have been exploited by multinational companies to their own advantage, often through legal channels, through tax optimization (Fuest, Parenti, \& Toubal, 2019). Multinational companies often transfer their income to low or no-tax countries, commonly known as tax havens (Fuest, Parenti, \& Toubal, 2019) to avoid taxes (Sasse, Watrin, \& Weiß, 2020). Therefore, governments are worried about the erosion of tax bases (Sasse, Watrin, \& Weiß, 2020).

The web giants GAFAM ${ }^{1}$ paid less than $10 \%$ of their income tax in 2016 outside the US (Broussolle, 2020). Moreover, according to the OECD, in 2015, tax avoidance created a loss of tax revenues (intended for the "citizen" public) of US\$100-240 billion per year, or 4\%-10\% of these revenues with $36 \%$ of multinational company's revenues artificially transferred to tax havens (Broussolle, 2020). For example, the scandal of the Panama Papers.

For France, for example, according to (Broussolle, 2020), in 2015, it lost around 14 billion euros, the equivalent

${ }^{1}$ Google, Apple, Facebook, Amazon \& Microsoft (Broussolle, 2020). 
of $29 \%$ of the corporate tax income (IS) ${ }^{2}$ which increased by $14 \%$ compared to 2012 and they represent 5 to 10 billion euros per year. Moreover, according to the author, hidden profits amounted to 36 billion euros in 2015, representing 1.6\% of France's GDP.

As a result, multinational companies engage in tax planning strategies (AISSAT \& MOKRANI, 2018) to carry out so-called aggressive tax optimization (Madiès, 2020) mainly through transfer pricing (Wier, 2020). However, the OECD has taken the initiative to set up a strategy to fight against this tax avoidance by implementing a "BEPS project" comprising 15 actions (Broussolle, 2020) among them, those that elucidate and resolve the tax challenges of transfer pricing (OCDE, 2017).

However, given the importance of the subject and its impact on tax revenues (Madiès, 2020), we are interested in the relationship between the BEPS transfer pricing actions and tax avoidance. In this study we investigate whether these actions mitigate tax avoidance by multinational companies. After several readings and researches we have been inspired mainly by the work carried out by (Broussolle, 2020), (Wier, 2020) and (Sasse, Watrin, \& Weiß, 2020) and the work of OECD to formulate our question, which is: Do the transfer pricing reforms contained in the BEPS project actions mitigate tax avoidance through transfer pricing manipulation?

To do this, based on the guidelines of (Kalika, 2016) this paper will be presented as follows:

Firstly, a theoretical background including the context of the study, an outline of the BEPS project and the above actions in our study, supported by a literature review. Secondly, we will conduct an empirical study on the subject and present the host company, Deloitte Algeria. Thirdly, we will discuss the results obtained from the empirical study with the literature review, and lastly, we will conclude the study hoping to have a possible answer to our question.

\section{Theoretical background}

In this section, we will deal with the theoretical part which will explain how the BEPS project came about, then we will briefly introduce the project and the related transfer pricing actions, and finally, we will present a state of the art of the recent scientific research on the studied topic « Contributions of the BEPS project on transfer pricing and tax avoidance $»$.

According to (EL ARABI, 2020), globalization and transformation of economies towards digitalization have led to inconsistencies and asymmetries with pre-established tax systems. These asymmetries are exploited by Multinational Enterprises to their own advantage (EL ARABI, 2020), result in a shift from non-double taxation to double non-taxation (Garbarino, 2020). Moreover, according to (Cahanin , 2018) after the financial crisis of 2007-2008, Multinational Companies are finding it more difficult to hide their presence in tax havens. Thus, the extent of tax avoidance on the global economic balance and the deterioration of public finances of countries (Cahanin ,2018). As a result, high political authorities and the G-20 have called on the OECD to find a solution, and for Multinational Enterprises to be obliged to be more transparent in their exchanges and keeping of financial and accounting statements (Cahanin , 2018).

The OECD has thus identified the BEPS problem and has set up a project called the BEPS project to combat this phenomenon of tax avoidance and transfer of profits to tax havens (OCDE, 2020).

\subsection{BEPS Project}

The BEPS $^{3}$ project is the initiative led by $\mathrm{OECD}^{4}$ to combat tax base erosion and profit shifting by multinational enterprises. It was started in 2012, launched in 2013 and developed in 2014 (Sasse, Watrin, \& Weiß, 2020). The project has three dimensions, coherence of tax systems; transparency of activities and results obtained; and substance, which means being subject to tax where the economic activity takes place (Sasse, Watrin, \& Weiß, 2020). To illustrate the alignment of income with real economic activity or substance, the authors (Sasse, Watrin, \& Weiß, 2020) give the example of Caterpillar, which declares $85 \%$ of its taxable

\footnotetext{
${ }^{2}$ IS, is a tax levied directly on natural or legal persons who have generated a profit from their economic activity (Bofipimpôts, 2021).

3 Base Erosion and Profit Shifting

${ }^{4}$ Organization for Economic Co-operation and Development, an international organization with 60 years of experience working with governments, policy makers and citizens to ensure prosperity, equality, opportunity, and well-being for all. It is about setting international standards, finding solutions to social, economic, and environmental challenges, improving economic performance, creating jobs, and combating international tax evasion (OECD, 2020).
} 
income in Switzerland, even though only $13 \%$ of its employees work in Switzerland.

To achieve this, the OECD identifies contemporary tax challenges and puts in place measures to address them, which are the 15 actions of the ambitious BEPS ${ }^{5}$ project (Bradbury, Hanappi, \& Moore, 2018) each of these actions is published in a report of more than 200 pages to explain in detail the orientations, objectives and contributions of each action (OCDE, 2020). Today the BEPS project has 139 countries (OCDE, 21).

Moreover, the OECD and the G-20 $20^{6}$ have the objective, through their work, of eliminating double taxation (finding solutions to avoid double taxation by means of tax treaties) (OCDE, 2015), However, with technological advances and the Covid-19 pandemic accelerated the use of digital (OCDE, 2018), tax systems encounter difficulties and generate double non-taxation, i.e. not being taxed in the resident country and the source country (EL ARABI, 2020) This is done through different tax planning strategies (Martin, 2018), mainly transfer pricing (Wier, 2020), Furthermore, according to (BENKENDIL \& EL GHAZALI, 2018) Intragroup trade constitutes almost $60 \%$ of world trade. Hence the interest of this study, and the choice of study which focuses on "transfer pricing" actions.

\subsection{What do we mean by transfer pricing?}

According to (SAIOUD \& SAIOUD , 2019) «Transfer pricing is the pricing of transactions between companies of the same group established in different countries. The challenge for tax administrations is to ensure that these transactions have led to an adequate determination of the tax base in each of the States concerned $»$ this definition (intra-group transaction prices) is supported by the work of (Fuest, Parenti, \& Toubal, 2019).

According to (Fuest, Parenti, \& Toubal, 2019) tax systems consider a multinational enterprise "as a set of distinct legal entities, each using separate accounting, [...] their profits are accounted for on a country-bycountry basis" as are branches and subsidiaries treated separately from the parent enterprise. As an example of how transfer pricing works.

\subsection{However, what about the BEPS transfer pricing actions addressed in our study?}

These include Action 8-10 and Action 13 which deal with transfer pricing:

According to (OCDE, 2015) actions 8-10 : « Aligning Transfer Pricing Outcomes with Value Creation» aims to ensure that transfer prices are aligned with the real economic activity (value creation) of the MNE. These actions ${ }^{7}$ reinforce the existing rules on the arm's length principle which, according to the (OCDE, 2015) the transaction price between two dependent companies is the same as with an independent company and aims to put in place alternative arrangements in the event that the arm's length price clarifications are not met.

As regards Action 13 : «Guidance on Transfer Pricing Documentation and Country-by-Country Reporting » (OCDE, 2015), according to (OCDE, 2015) the action consists of introducing the obligation to multinational companies with a turnover of more than 750 million euros (Bradbury, Hanappi, \& Moore, 2018) to declare its income and profits in a document called a "country-by-country declaration", where all tax authorities have a right of review of the profits of the multinational, in order to encourage transparency and declaration of the amount and location of the entity's profits (OCDE, 2015).

Inclusive framework on BEPS: According to (Bradbury, Hanappi, \& Moore, 2018) and (OCDE, 2018), Following the request of the G-20 and since 2016, the OECD has put in place this framework to ensure that interested jurisdictions and developed countries, in particular, participate "on an equal footing" in BEPS actions. This framework will allow its users to follow the implementation of the project and any developments.

Considering the progress of scientific research on the BEPS project, we consider it necessary to share with you some contemporary results of researchers on the influence of the BEPS project on tax avoidance and following this study we will develop our hypotheses that could possibly respond to the problematic posed based on the scientific articles studied.

The study conducted by (Bradbury, Hanappi, \& Moore, 2018) and inputs from action $11^{8}$ of the BEPS project

\footnotetext{
${ }^{5}$ See Appendix 1.

${ }^{6}$ Group 20: International forum created in 1999 and composed since 2008 of heads of state and government of 20 most developed countries (G-20, 2021).

7 Action 08: "Transaction of intangible assets"; Action 09: "Contractual allocation of risks and resulting benefits"; Action 10: "High risk transactions" (OECD, 2015).

8 "Measuring and monitoring BEPS data", (OECD \& G-20, 2015).
} 
aim to present the current state of international taxation at the time of the BEPS project; to demonstrate the methodological difficulties encountered by researchers in estimating base erosion and profit shifting (BEPS) on a global scale; to analyze recent methods used to assess the tax impact of BEPS; and to present contemporary international taxation at the time of the BEPS project using OECD corporate income tax statistics.

Based on a literature review, the authors (Bradbury, Hanappi, \& Moore, 2018) argue that data for BEPS analysis is available at the macro level but not at the micro level and is not accessible. In addition, there are difficulties including the choice of tax rate to be used to estimate BEPS and the distinction between BEPS and real activity.

The authors (Bradbury, Hanappi, \& Moore, 2018) emphasize the need to distinguish between real activity and BEPS, i.e., the notion of substance, and from this stem the analytical difficulties of the said distinction. They find that despite researchers obtaining estimates of revenue losses using econometric methods, they still encounter gaps in the tax rate used and the distinction between real activity and BEPS.

(Bradbury, Hanappi, \& Moore, 2018) deduce that there is a lack of relevant but available data, so the Action 11 report recommends a set of suggestions to improve the quality of available data, among them the obligation of a multinational company with a turnover exceeding 750 million euros to report its profits in the country-bycountry declaration. However, according to (Bradbury, Hanappi, \& Moore, 2018) the steps taken by the OECD and the G-20 on transparency, reality and quality of data and statistics on multinational enterprises will greatly help researchers, policy makers and the public on BEPS.

In his article, (Wier, 2020) proves that the manipulation of transfer prices by multinational companies based in South Africa, a developing country, is done to transfer profits to tax havens. (Wier, 2020) assesses the impact of the BEPS project's contribution to transfer pricing in the said country, using an econometric method, using South African customs data, of merchandise imports from 2011 to 2015 newly obtained by a newly constructed confidential administrative level. To make, (Wier, 2020) assesses the differences between transfer prices and arm's length prices, (Wier, 2020) concludes that the transfer pricing reform proposed by the BEPS project has not been able to mitigate the long-term mispricing of transfer pricing that allows profits to be shifted from multinational enterprises. He observes that transfer pricing mispricing falls just after the BEPS project's input but regains its level sometime later, driven by the limited effort of the tax administration sometime later.

According to the author, the tax losses in percentage terms are insignificant compared to the total corporate taxes paid, (Wier, 2020) the transfer of benefits is mainly through intangible assets, as also supported by (OCDE \& G-20, 2015). According to (Wier, 2020), Many academics and senior officials believe that automatic taxpayer notification and auditing is the solution to counteract transfer pricing errors, but that the tax authorities do not have the means to do this because, according to (Wier, 2020), this numerical operation costs thousands of dollars in tax losses, which confirms the hypothesis of his study, namely, the lack of resources available to the tax authorities for the application of arm's length pricing. To this end, (Wier, 2020) encourages the approach of the OECD and the $\mathrm{IMF}^{9}$ for the application of a digital tax.

In their article (Sasse, Watrin, \& Weiß,2020), aim to study the alignment of profits of multinational enterprises and value creation due to its importance in contributing to the tax base. The authors (Sasse, Watrin, \& Weiß, 2020), compare these variables from 2009 to 2016 before and after the publication of the BEPS actions in 2014, to identify possible changes. They conclude that multinational companies are adapting to and anticipating the new regulations.

Through their article, (Olatunji \& Adebayo , 2020) analyses the effect of the BEPS project on revenue generation in Nigeria, using quarterly data from 2013 to 2017 on Nigeria's tax revenue and gross domestic product (GDP) before and after BEPS. The authors perform their analysis using statistical tools and manage to demonstrate that the BEPS project has had a positive effect on Nigeria's tax revenues (increase in revenues compared to the pre-BEPS situation), this also demonstrates, according to (Olatunji \& Adebayo , 2020) that multinational companies comply with the BEPS transfer pricing and tax revenue reforms on their own volition.

From these articles, we can formulate our first hypothesis which could be an answer to our problem, namely the relationship between the new reforms carried out by the OECD and the G-20 through the BEPS project in

\footnotetext{
${ }^{9}$ International Monetary Fund.
} 
transfer pricing and tax avoidance.

Dypothesis 01: BEPS transfer pricing reforms have a positive impact on tax revenues (Olatunji \& Adebayo , 2020) in the short term (Wier, 2020).

Given that the tax revenue ${ }^{10}$ is an amount collected by governments from different taxes (OCDE, 2020), and by definition, tax avoidance ${ }^{11}$ is to reduce tax liability (Shukla, Pandey, \& Lingam, 2020) i.e. reduction of the tax base by the taxpayer to pay the least tax (OCDE, 2020), This leads to reduced tax revenue collection by governments due to tax avoidance.

However, based on this observation and by extension, we allow ourselves to improve our hypothesis as follows:

$>\quad$ Hypothesis 01: BEPS transfer pricing reforms have a positive impact on tax avoidance (Olatunji \& Adebayo , 2020) in the short term (Wier, 2020).

To this end, we take the liberty of reformulating our hypothesis so that it can respond exactly to our problem while retaining the authors' meaning and results,

$>\quad$ Hypothesis 01: Yes, BEPS transfer pricing reforms mitigate tax avoidance (Olatunji \& Adebayo, 2020) in the short term (Wier, 2020).

All the papers reviewed put the relationship between tax avoidance and tax revenues, i.e. that tax avoidance could reduce a country's tax revenues, supported by the work of (OCDE \& G-20, 2015), To this end, the study of the contribution of BEPS transfer pricing actions on tax avoidance (possible decrease or increase of tax avoidance) is studied through the parameter "tax revenue".

The authors (Legenzova, Levišauskaite, \& Kundelis, 2017) aim to identify the parameters and methods for evaluating the contributions of the BEPS project at the micro level, and to use these results to measure the impact of the BEPS project on a group of companies.

To achieve this (Legenzova, Levišauskaite, \& Kundelis, 2017) compares scientific and professional contributions. The authors find that the methods used to assess the impact of the BEPS project at the micro level are different from those used at the macro level. They conduct a case analysis to assess the impact of the BEPS project on a single group of companies in Lithuania, namely Business Group LT. The result of this analysis at the level of the business group is, that 05 actions out of the remaining 15 actions of the OECD and G-20 project are considered "relevant" and "operational" on this group. The authors state that these 5 actions do not have a significant imminent impact on tax matters; however risks related to the BEPS project arise, accompanied by action plans that combat the "negative effects" of the BEPS actions, which must be implemented.

(Legenzova, Levišauskaite, \& Kundelis, 2017) argue that the impact of BEPS measures is difficult to assess due to "data limitations, complexity and interdependence of global business operations".

Through their article, (Bolwijn, Casella , \& Rigo, 2018) study the link between foreign direct investment (FDI) and tax base erosion and profit shifting (BEPS) by multinational enterprises. They show that tax avoidance by multinationals through FDI and offshore investments leads to leakage of development finance. (Bolwijn, Casella , \& Rigo, 2018) conclude that, to overcome this, cooperation and synergies between international taxation and investment are needed.

The authors (Klemm \& Liu, 2019) examining the impact of profit shifting by multinational enterprises on the economic activity that for them represents real (tangible) investment, and tax competition. Transfer activities are widespread among economic entities to reduce their tax base, and result in the manipulation of transfer prices. Using simulation of the impact of profit shifting on investment and a strong support of the literature review, the authors (Klemm \& Liu, 2019) infer that transferring profits leads to a systematic decrease in the cost of capital in all countries regardless of the tax rate, so the rigidity of transfer pricing regulations has a significant negative effect on the tangible assets of multinational enterprises.

With the help of readings of the authors' articles (Klemm \& Liu, 2019) and (Bolwijn, Casella , \& Rigo, 2018), we can formulate the second hypothesis which runs counter to the first hypothesis :

\footnotetext{
${ }^{10}$ Full definition in the "Conceptual Framework" section.

${ }^{11}$ Full definition in the "Conceptual Framework" section.
} 
$>\quad$ Hypothesis 02: BEPS transfer pricing reforms have a negative impact on investment (Klemm \& Liu, 2019).

Especially since there is a direct link between "tax revenue" and "investment", as according to (Niang, 2020) "Tax revenues can play an important role in domestic resource mobilization, as they give governments the financial means to invest in development". However, by extension, we can improve on the work of (Niang, 2020) our hypothesis as follows:

$>\quad$ Hypothesis 02: BEPS transfer pricing reforms have a negative impact on tax revenues (Klemm \& Liu, 2019).

And considering the relationship of tax revenues and tax avoidance studied in the formulation of our first hypothesis, hypothesis 02 will be reformulated as follows:

$>\quad$ Hypothesis 02: BEPS transfer pricing reforms have a negative impact on tax avoidance (Klemm \& Liu, 2019).

At the same time, we will reformulate the hypothesis so that it can be in line with our study problem while keeping the results obtained and the related meanings:

$>\quad$ Hypothesis 02: No, BEPS transfer pricing reforms do not mitigate tax avoidance (Klemm \& Liu, 2019) (Niang, 2020).

\subsection{Theoretical synthesis}

Reading the above-mentioned articles, we note that as a result of the scandals and loss of tax revenues amounting to between 100 and 240 billion dollars per year (Broussolle, 2020), that the fight against tax avoidance and ensuring that multinational companies are taxed where value is created is a key call for governments (Bolwijn, Casella , \& Rigo, 2018). For this purpose, the (OCDE, 2015) set up the ambitious 15action BEPS project, started in 2012 to combat tax avoidance.

Note that, according to the work of (Wier, 2020), (Sasse, Watrin, \& Weiß, 2020), (Olatunji \& Adebayo , 2020) and (Bradbury, Hanappi, \& Moore, 2018), the BEPS project reforms in the area of transfer pricing has had a positive impact on tax revenues (Olatunji \& Adebayo , 2020) in the short term (Wier, 2020). All the more so as the tax revenue ${ }^{12}$ is an amount collected by governments from different taxes (OCDE, 2020), and by definition, tax avoidance ${ }^{13}$ is to reduce tax liability (Shukla, Pandey, \& Lingam, 2020) i.e. reduction of the tax base by the taxpayer to pay the least tax (OCDE, 2020), this leads to reduced tax revenue collection by governments due to tax avoidance. However, the BEPS transfer pricing reforms can be directly linked to tax avoidance and therefore the effectiveness of BEPS actions dealing with transfer pricing and their role in combating tax avoidance (Olatunji \& Adebayo , 2020) in the short term (Wier, 2020) because, according to the latter, in the long term, the lack of control by the tax authorities has not had an effect on these transfer pricing manipulation practices, thus increasing tax avoidance (Wier, 2020).

All the articles studied put the relationship between tax avoidance and tax revenues, i.e. tax avoidance could reduce a country's tax revenues in other words tax avoidance is the cause of tax base erosion, supported by the work of (OCDE \& G-20, 2015), To this end, the study of the contribution of BEPS transfer pricing actions on tax avoidance (possible decrease or increase of tax avoidance) is studied through the parameter "tax revenue".

The authors (Klemm \& Liu, 2019) and (Bolwijn, Casella , \& Rigo, 2018), We point to the negative effect of the BEPS transfer pricing reforms on tangible investment. Knowing that there is a direct link between "tax revenue" and "investment", as according to (Niang, 2020) "Tax revenues can play an important role in domestic resource mobilisation, as they give governments the financial means to invest in development». In addition to what has already been mentioned, regarding the study of tax avoidance using tax revenues, it is noted that according to (Niang, 2020) and (Klemm \& Liu, 2019), the BEPS transfer pricing reforms have a negative impact on tax revenues and the failure to combat tax avoidance.

It is also noted that according to (Legenzova, Levišauskaitè, \& Kundelis, 2017) The impact of BEPS measures remains difficult to assess by researchers and specialists due to the complexity of the phenomenon, intra-group transactions and difficulty in accessing data.

\footnotetext{
${ }^{12}$ Full definition in the "Conceptual Framework" section.

${ }^{13}$ Full definition in the "Conceptual Framework" section.
} 
We were able to develop two hypotheses from the literature review and in the second section of this paper, the empirical study; we will test these two hypotheses in the field.

\section{Method and data}

\subsection{Method}

In order to respond to the problem posed, we intend to carry out a qualitative study through interviews, given the scope of the study (OCDE, 2015) so as not to stray too far from the objective of this document, the interviews will be half-guided, i.e. semi-structured interviews (Imbert, 2010). This interview is with international tax specialists and individuals from the tax authority in Algeria, the interviews were conducted face to face and using an online form.

The structure of this semi-structured interview and its content are based on the following works: Rogers , H., \& Oats, L. (2021, Juillet 01), Cools, M., \& Rossing, C. P. (2020). International Transfer Pricing: MNE Knowledge Dependency on External Tax Consultants ${ }^{14}$, Arafat, Y. (2020). Transfer pricing and it's use for tax avoidance by corporations ${ }^{15}$.

\subsection{Limitations of the empirical study}

It is important to note that our study does not exhaustively cover all the content and details of the BEPS transfer pricing actions, we seek to deal with the subject in a comprehensive way and to answer our question based on the articles studied given the complexity of these actions and their scope (OCDE, 2015) and the lack of technical expertise on our part in the area of BEPS. We had difficulties in estimating our population and the accuracy of our sample, as well as the difficulty in collecting responses from our sample. As a result, our study sample is not representative and could bias the results obtained and those of the literature review. In the field, we encountered difficulties that could also bias our study, because not all individuals have a perfect grasp of the subject, according to our field experience, and are knowledgeable on the subject. We met very few people who were able to help us answer this interview.

As we conducted some interviews face-to-face and others online using a form, we found that using the form did not really allow us to get answers to all the questions with the desired explanations unlike the face-to-face interview, but the online form is still a useful tool for the interviews.

\subsection{Presentation of the interview}

Table 1. The questions for the semi-structured interview and their objectives

\begin{tabular}{|c|c|c|}
\hline Section & Questions & Purpose of each question \\
\hline \multirow[t]{3}{*}{$\begin{array}{l}\text { Section } 01 \text { : sample's } \\
\text { characteristics }\end{array}$} & $\begin{array}{l}\text { 1. You are in : Multinational Company or Tax } \\
\text { Administration? }\end{array}$ & $\begin{array}{l}\text { This question will help us to characterise our sample, } \\
\text { given that our study, according to the literature review, } \\
\text { involves two major actors, namely the multinational } \\
\text { enterprise and the tax administration. }\end{array}$ \\
\hline & $\begin{array}{l}\text { 2. How long have you been working with transfer } \\
\text { pricing, and what is your professional experience } \\
\text { ? }\end{array}$ & $\begin{array}{l}\text { Professional experience in transfer pricing gives us an } \\
\text { idea of the interviewee's practicality in transfer pricing } \\
\text { and whether the interviewee has a background in } \\
\text { taxation. }\end{array}$ \\
\hline & 3. Professional status & $\begin{array}{l}\text { Status is not a really important variable in our study, but } \\
\text { it will help us to define the sample studied. }\end{array}$ \\
\hline \multirow[t]{4}{*}{$\begin{array}{l}\text { Section } 02 \text { : Motivations and } \\
\text { modalities of BEPS }\end{array}$} & 4. Do you think tax avoidance is illegal? & $\begin{array}{l}\text { There is often confusion between fraud and tax avoidance } \\
\text { (Berrahi, 2016), and one would like to know whether for } \\
\text { the tax authority's avoidance is illegal contrary to the } \\
\text { opinions of individuals in multinational companies. }\end{array}$ \\
\hline & $\begin{array}{l}\text { 5. What do you think drives multinational } \\
\text { companies to evade taxes through transfer } \\
\text { pricing? }\end{array}$ & $\begin{array}{l}\text { The aim is to understand the possible motivations for tax } \\
\text { avoidance, other than reducing the tax rate by } \\
\text { manipulating the prices of transfer. (Sasse, Watrin, \& } \\
\text { Weiß, 2020) }\end{array}$ \\
\hline & $\begin{array}{l}\text { 6. How do multinational companies avoid taxes } \\
\text { with transfer pricing? }\end{array}$ & $\begin{array}{l}\text { The aim is to get an idea of the mechanisms of tax } \\
\text { avoidance vis-à-vis the specialists. }\end{array}$ \\
\hline & $\begin{array}{l}\text { 7. Do you think that tax havens facilitate the } \\
\text { transfer of profits through transfer pricing? }\end{array}$ & $\begin{array}{l}\text { Since according to the literature review, tax losses have } \\
\text { a direct relationship with tax havens, we investigate this } \\
\text { relationship between the two variables in the field. }\end{array}$ \\
\hline \multirow[t]{2}{*}{$\begin{array}{l}\text { Section } 03: \text { BEPS project } \\
\text { transfer pricing actions and tax } \\
\text { avoidance }\end{array}$} & $\begin{array}{l}\text { 8. Do you think that the BEPS project's actions on } \\
\text { transfer pricing can mitigate tax avoidance by } \\
\text { multinational companies in the long term? }\end{array}$ & \multirow[t]{2}{*}{$\begin{array}{l}\text { The purpose of these two questions is to test in the field } \\
\text { whether there can be short- or long-term changes as } \\
\text { studied by (Wier, 2020). }\end{array}$} \\
\hline & 9. Do you think that the BEPS transfer pricing & \\
\hline
\end{tabular}

\footnotetext{
14 (Cools \& Rossing, 2020);

15 (Arafat, 2020).
} 


\begin{tabular}{|c|l|l|}
\hline & $\begin{array}{l}\text { actions can mitigate tax avoidance by } \\
\text { multinational companies in the short term ? }\end{array}$ & \\
\hline & $\begin{array}{l}\text { 10. What do you think of the arm's length method, } \\
\text { is it sufficient to counteract tax avoidance through } \\
\text { transfer pricing ? }\end{array}$ & $\begin{array}{l}\text { It can be seen that according to (OCDE, 2015), (Sasse, } \\
\text { 2019) the arm's length principle could prove ineffective } \\
\text { and have limitations. For this purpose, we would like to } \\
\text { test this in the field. }\end{array}$ \\
\hline & $\begin{array}{l}\text { 11. What do you think of multinationals setting up } \\
\text { subsidiaries in low-tax countries to remit income } \\
?\end{array}$ & $\begin{array}{l}\text { On reading several articles, we note that a tax haven has } \\
\text { characteristics that appeal to investments, nevertheless } \\
\text { the tax administration fights against this phenomenon of } \\
\text { profit transfer, we seek to know if this kind of practice is } \\
\text { acceptable from both points of view (Cahanin, 2018). }\end{array}$ \\
\hline Section 04: Interview & 12. How long did you spend in this interview? & $\begin{array}{l}\text { The aim is to estimate the time allocated and the interest } \\
\text { in this interview for the characteristics of the interview. }\end{array}$ \\
\hline
\end{tabular}

Source: Compiled by authors.

\subsection{Interpretation}

The semi-structured interview was conducted on site with one individual and for the other respondents it was online using a form that was sent to them by e-mail, on LinkedIn and was also shared in Facebook groups specializing in Taxation and International Taxation.

To the best of our knowledge, we sent our interview to 30 people specialized in taxation and international taxation working in Multinational Companies or Tax Administrations. Nevertheless, we had a low response rate of $16 \%$.

The sampling technique used is stratified random sampling, which consists of dividing the population into homogeneous groups called strata. In our study we have two main strata, i.e. individuals who work in multinational companies or in tax administrations.

Despite this, the results of our field study are as follows :

According to the results, our sample consists of $80 \%$ of individuals in Multinational Companies and only $20 \%$ in Tax Administration. Among them, we find $40 \%$ of specialists with 5 years of professional experience, $20 \%$ with 2 years of experience, $20 \%$ with 3 years and $20 \%$ with 20 years of professional experience.

As regards the status of the respondents, $60 \%$ are Tax Managers, 20\% Deputy Directors and 20\% Tax Advisors. Interviews lasted an average of 22 minutes.

When asked whether tax avoidance is legal or illegal, the majority of respondents, $60 \%$, said that tax avoidance is illegal for a number of reasons, namely : depriving the resident country of tax revenue, transferring profits to countries other than the one where the company resides, and unbalancing the state's budgetary plan, followed by a "budget crisis" and so-called "negative" implications on the "economic balance of the state", and one of the respondents described tax avoidance as "hindering tax legislation and regulation". $40 \%$ of the other respondents do not consider tax avoidance to be illegal, highlighting the concept of "tax fraud" as an illegal practice, unlike tax avoidance, and one of the respondents adds that:

"The BEPS project fights against tax avoidance because for us we are all equal before the tax and all companies must pay the tax, whereas multinationals make a lot of money, and they avoid this tax».

What motivates multinational companies to engage in tax avoidance through transfer pricing is, according to the respondents, tax optimization (40\% of respondents), reduction of the tax base (40\% of respondents) and $20 \%$ think it is the high rate of corporation tax.

According to $60 \%$ of the respondents, MNEs inflate their expenses in high-tax countries and decrease their revenues in low-tax countries to avoid taxes with the help of transfer pricing, $20 \%$ of them think it is with the help of undercutting the tax base and 20\% listed several tax avoidances practices with the help of transfer pricing, to know:

«Increase or decrease of purchase or sale prices; Payment of excessive or unrequited royalties; Granting of loans without interest or at a reduced rate; Waiver of interest stipulated by loan contracts; Granting of an advantage out of proportion to the service obtained, or any other means; As well as any other means that may constitute abnormal transfers $»$.

According to all respondents in our sample, tax havens facilitate the transfer of profits through transfer pricing because of their advantages: low or zero corporate tax rate, bank, and tax secrecy as "they do not sign bilateral agreements in collaboration". 
All the sample studied believe that in the short term, BEPS transfer pricing actions can mitigate tax avoidance as many countries have signed up and nowadays the practices of multinational companies follow BEPS actions.

In the long term, $80 \%$ of respondents think that yes, BEPS transfer pricing actions will mitigate tax avoidance, as BEPS transfer pricing actions mitigate avoidance in the short term, it is necessarily the same in the long term and over time more countries will join the project so more alignment with the actions and less tax avoidance. Nevertheless, $20 \%$ of our sample thinks that it is possible that they will not reduce tax avoidance with new avoidance practices by MNEs.

As far as the arm's length principle is concerned, all respondents find it to be a successful and very effective method, even if it has limitations that were not developed by the respondents.

Most of the respondents believe that multinationals that set up subsidiaries in tax havens in order to remit their profits have the right to do this as it is legal and "economically" justified, $20 \%$ of respondents believe that it is a tax avoidance scheme and the remaining $20 \%$ believe that this type of practice is not tax compliant and that the multinational company would risk being penalized and having to pay penalties.

At the end of the semi-structured interview, the respondents were asked for any recommendations based on their experience in Taxation and International Taxation. $80 \%$ gave recommendations, $50 \%$ of the $80 \%$ recommended that more countries join the BEPS project to fight tax avoidance, and the remaining $50 \%$ gave their opinion on the obligation to file country-by-country tax returns, which they consider to be the best solution for more transparency and the reduction of tax avoidance.

From our fieldwork and considering the "majority" of respondents, we conclude that, according to them, tax avoidance is illegal but MNEs avoid tax with legal practices including tax optimization by using transfer pricing, transferring income, and opening subsidiaries in tax havens. Our sample leads us to the conclusion that BEPS transfer pricing actions mitigate tax avoidance in the short term and necessarily in the long term as other countries join the project and align and comply with the actions taken. This mitigation results, according to most respondents, from the effectiveness of the arm's length principle despite the limitations that may be encountered, and from transparency vis-à-vis tax administrations and authorities through the country-bycountry reporting requirement.

\section{Discussion}

After having collected some opinions of specialists in Taxation and International Taxation and the articles studied, we find that multinational companies want to pay less tax (tax optimization) by minimizing their tax base and transferring their profits to tax havens that offer a low tax rate and other advantages such as banking secrecy. Nevertheless, our theoretical study suggests that tax avoidance is according to several authors (Berrahi, 2016), (SAIOUD \& SAIOUD , 2019) and (Shukla, Pandey, \& Lingam, 2020) the reduction of the tax base through the use of legal tax planning strategies, while the majority of our test sample suggests that tax avoidance is illegal because of the erosion of the tax base, thus reducing tax revenues by shifting income to tax havens and depriving states of taxes, which in turn affects the lives of citizens. The results of the empirical study and those of the literature review converge towards the same idea of the motivations that drive companies to tax avoidance. Note that, it is tax optimization, the high tax rate.

In the area of transfer pricing the results of (Wier, 2020) mention that in the short term the actions of the BEPS project (action 8-10 and action 13) have an effect on transfer pricing as long as the tax administration controls multinationals, our sample confirms this and think that yes in the short term the related actions remain an adequate solution (arm's length principle and more transparency) and think that even in the long term it could have a positive effect and reduce tax avoidance, in contrast, (Wier, 2020) finds that in the long run multinational companies have gone back to their old ways and have been able to manipulate transfer prices despite the transparency established by the action 13 , the author explains this by new business practices and the lack of control by the tax administration. The notion of new practices can also be found in (Sasse, Watrin, \& Weiß, 2020) who, at the end of their study, find that multinational companies anticipate and adapt their structures, moreover according to (OCDE, 2015), in the event that the OECD finds that the arm's length principle has not been respected, it could remedy this by putting in place alternative arrangements.

The empirical study, on the other hand, extrapolates from our sample and believes that if compliance with actions and new regulations and alignment of real activity with the reporting and taxation of profits of multinational enterprises in the short term, this will necessarily be the case in the long term as there will be new variables and factors that enter into the analysis which are possible new adherents to the project and 
possible new regulations of actions adapted to the economy and business practices. However, it is inferred from the results that BEPS actions dealing with transfer pricing, in the short term, mitigate tax avoidance by multinational enterprises, and in the long term they could, but it is not clear until this possibility can be tested.

\section{Conclusion}

The BEPS project, led by the OECD since 2012, is constantly evolving to best adapt to contemporary economic challenges and to ensure that fairness and equality before tax is achieved by all companies, especially multinationals. Multinational companies have developed legal practices that draw on tax planning strategies to optimize their tax base, which leads to tax avoidance and consequently to the erosion of the tax base and the payment of less tax. This is often done by manipulating intra-group transfer prices and transferring profits to tax havens, always with the aim of paying less tax. However, even if these practices remain legal, their excesses have serious consequences for economic equilibrium, which is why the G-20 and the governments and countries are helping each other on an equal footing, as the OECD points out, to counteract this.

The ambitious BEPS project provides several reforms for each identified tax challenge. Despite their complexity and breadth, our study focused on transfer pricing, namely Action 8-10 and Action 13, and whether the contributions of these actions mitigate tax avoidance by multinational enterprises. Based on a literature review and an empirical study with international tax specialists, it was found that immediately after the publication of the BEPS actions, companies aligned their profits where their value creation resides, thus reducing tax avoidance and not eroding the tax base and profit shifting, However, we note that according to other authors over time these reforms may not have an effect as the review results suggest that companies are anticipating the new BEPS rules and seeking to realize their self-interest contrary to the empirical results which lead us to believe that short term success could strongly be the case in the long term as over time more countries adhere to the project and the country-by-country reporting requirement will increase transparency. Having said this, we can then confirm our first hypothesis: that the BEPS project's transfer pricing inputs mitigate tax avoidance in the short term, and following the results obtained, we can refute the second hypothesis that BEPS actions dealing with transfer pricing do not mitigate tax avoidance. On the other hand, when reading the work of (Wier, 2020) and (Sasse, Watrin, \& Weiß, 2020), we ask, is the strengthening of tax administration control a factor that mitigates tax avoidance by multinational enterprises? This question could be addressed in future research, which would be of great interest to us to know whether this is true. When we tried to study our topic by adopting a scientific methodology, we learned where and how to look for information and use references, nevertheless we encountered difficulties because the BEPS project is an ambitious and complex project, and it requires technical competence and means for experimentation and study. Moreover, our internship in the Tax \& Legal department at Deloitte Algérie was very constructive in a short period of time, as we were able to learn how to search for information in Algerian legislation and understand it, understand some of the approaches and thoughts of the tax authorities and the practice of some cases of tax compliance in terms of tax returns and other problems encountered. These acquisitions served as a basis of understanding and tools for the realization of this study.

\section{Appendix}

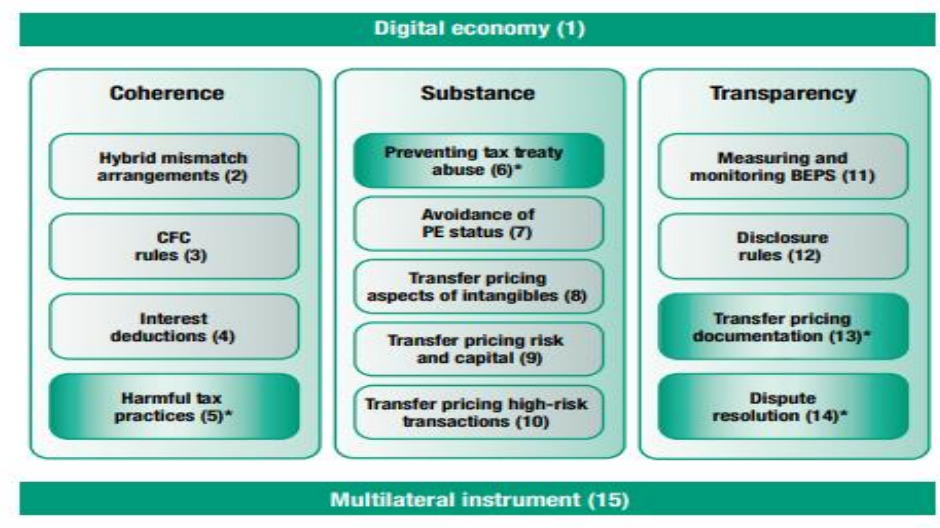

Figure 1. The 15th actions of the BEPS project 


\section{Acknowledgement}

We gratefully acknowledge the invaluable help of the Tax \& Legal team of Deloitte Algeria as well as all the others of the different departments for their advice, follow-up and help in the realization of this article.

\section{References}

1. Aissat, A., Mokrani, A. (2018). Enjeux de la fiscalité sur les stratégies de localisation des firmes multinationales. Revue des Réformes Economiques et Intégration En Economie Mondiale. [Issues of taxation on the localization strategies of multinational firms. Review of Economic Reforms and Integration in the World Economy]. [Google Scholar]

2. Arafat, Y. (2021). Transfer pricing and it's use for tax avoidance by corporations. Master thesis. [Google Scholar]

3. Benkendil, H., \& El Ghazali, M. (2018, Juin). Optimisation fiscale des groupes : quel est l'impact des prix de transfert et l'intégration fiscale sur la performance financière au Maroc. Revue du Contrôle de la Comptabilité et de l'Audit(05). [Group tax optimization: what is the impact of transfer pricing and tax integration on financial performance in Morocco. Review of Accounting and Audit Control (05)]. [Google Scholarl

4. Berrahi, K.-e. (2016, Décembre). L'évasionet la fraude fiscales : Un grand défi de lutte contre l'informel. Revue Algérienne des Finances Publiques(06). [Tax avoidance and fraud: A big challenge in the fight against the informal sector. Algerian Review of Public Finances (06)]. [Link]

5. Bofipimpôts. (2021). Récupéré sur Bulletin Officiel des Finances Publiques-Impôts. [Retrieved from the Official Bulletin of Public Finances-Taxes]. [Link]

6. Bolwijn, R., Casella , B., \& Rigo, D. (2018). An FDI-driven approach to measuring the scale and economic impact of BEPS. Transnational Corporations, 25(2). [Google Scholar]

7. Bourlès, R., \& Henriet, D. (2017). Théorie des jeux. [Game theory]. [Link]

8. Bradbury, D., Hanappi, T., \& Moore, A. (2018). Estimating the fiscal effects of base erosion and profit shifting: data availability and analytical issues. Transnational Corporations, 25(2). [Google Scholar]

9. Broussolle, D. (2020). Où en sont la taxation des entreprises numériques et la lutte contre l'évitement fiscal ? Bulletin de l'observation des politiques économiques en Europe. [Where are the taxes of digital companies and the fight against tax avoidance? Bulletin of the Observation of Economic Policies in Europe]. [Google Scholar]

10. Cahanin , P. (2018). L'évasion Fiscale Internationale Des Entreprises.[ International Corporate Tax Escape]. Gestion et finances publiques, 66-71. [Google Scholar]

11. Chaouche, N. Y. (2019). Le régime fiscal des implantations internationales d'entreprises, le cas de l'Algérie. HAL Archives ouvertes. [The tax regime for international business establishments, the case of Algeria. HAL Open Archives]. [Google Scholar]

12. Conan, M. (2013). Gaston Jèze et l'utilité de la dépense publique, L'élaboration d'une théorie générale des dépenses publiques. [Gaston Jèze and the Utility of Public Spending, The Development of a General Theory of Public Spending]. [Link]

13. Cools, M., \& Rossing, C. P. (2020). International Transfer Pricing: MNE Knowledge Dependency on External Tax Consultants. [Google Scholar]

14. El Arabi, A. (2020). La planification fiscale des multinationales à l'ére de la dématérialisation économique. [The tax planning of multinationals in the era of economic dematerialization]. Journal of quantitative and qualitative research in economic and administrative sciences, 2(1). [Link]

15. Fuest, C., Parenti, M., \& Toubal, F. (2019). Fliscalité internationale des entreprises: quelles réformes pour quels effets? Conseil d'analyse économique, (54). [International corporate taxation: what reforms for what effects? Economic Analysis Council]. [Google Scholar]

16. Garbarino, C. (2020). The impact of the OECD BEPS project on tax treaties: Access, entitlement and investment protection. Bocconi Legal Studies Research Paper, (3730030). [Google Scholar] 
17. Imbert, G. (2010). L'entretien semi-directif: à la frontière de la santé publique et de l'anthropologie. [Semi-structured interview: at the border between public health and anthropology]. Recherche en soins infirmiers, 3(102), 23-34. [Google Scholar]

18. Klemm, A., \& Liu, L. (2019, December). The Impact of Profit Shifting on Economic Activity and Tax Competition. International Monetary Fund. [Google Scholar]

19. Legenzova, R., Levišauskaitè, K., \& Kundelis, E. (2017). Estimating an impact of base erosion and profit shifting (BEPS) countermeasures - a case of business group. Oeconomia Copernicana, 4. [Google $\underline{\text { Scholar] }}$

20. Madiès, T. (2020). L'optimisation fiscale des entreprises multinationales. [The tax optimization of multinational companies] (L. Découverte, Éd.) La concurrence fiscale internationale, 71-89. [Link]

21. Martin, J. (2018). Planification fiscale des sociétés québécoises et recours aux paradis fiscaux. [ Tax planning of Quebec companies and use of tax havens]. [Link]

22. Niang, F. (2020). Le rôle de la fiscalité dans le financement du développement en Afrique. [The role of taxation in financing development in Africa]. Afrique et développement, 65(1). [Link]

23. OCDE. (2015). L'imposition des entreprises multinationales. Organisation de Coopération et du Développement Economique. [Link]

24. OCDE. (2017). Renforcement des capacités de BEPS et de prix de transfert. [Capacity building for BEPS and transfer pricing]. OCDE, Fiscalité et Développement. [Link]

25. OCDE. (2018). Cadre inclusif sur le BEPS de l'OCDE et le G-20. [Inclusive Framework on OECD BEPS and the G-20]. OCDE. [Link]

26. OCDE. (2018). Les défis fiscaux soulevés par la numérisation de l'économie. [The fiscal challenges raised by the digitization of the economy]. [Link]

27. OCDE. (2020). Digital Economy Outlook 2020. [Link]

28. OCDE. (2021). Members of the OECD/G20 Inclusive Framework on BEPS. OCDE. [Link]

29. OCDE, \& G-20. (2015). Projet OCDE/G20 sur l'érosion de la base d'imposition et le transfert de bénéfices, Rapports finaux. [OECD / G20 Base Erosion and Profit Shifting Project, Final Reports].

30. Olatunji, O. C., \& Adebayo , O. C. (2020). Effect of Base Erosion and Profit Shifting on Revenue Generation Nigeria. Universal Journal of Accounting and Finance. [Link]

31. Rogers, H., \& Oats, L. (2021). Transfer pricing: changing views in changing times. Accounting Forum. [CrossRef]

32. Saioud, K., \& Saioud, A. (2019). Les conventions fiscales internationales comme moyen de résolution des problèmes de la fiscalité internationale. [International tax treaties as a means of solving international tax problems]. Review of economic papers, 3(2). [Link]

33. Sasse, K. S., Watrin, C., \& Weiß, F. (2020). The alignment between reported profits and real activity in. Journal of International Accounting, Auditing and Taxation, 40. [Link]

34. Shukla, G., Pandey, S. K., \& Lingam, S. (2020). Tax effects of treaty shopping and OECD's BEPS implications. FIIB Business Review. [Link]

35. Wier, L. (2020). Tax-motivated transfer mispricing in South Africa: Direct evidence using transaction data. Journal of Public Economics. [CrossRef] 